\title{
Lean Implementation: The Progress and the future challenges of Apparel Industry to achieve the Manufacturing Competitiveness
}

\author{
Abul Bashar ${ }^{1 *}$, M. Ahsan Akhtar Hasin ${ }^{2}$ \\ ${ }^{1}$ School of Business, Independent University, Bangladesh \\ ${ }^{2}$ Industrial \& Production Engineering, Bangladesh University of Engineering \& Technology \\ *Corresponding e-mail: bashar@iub.edu.bd.
}

\begin{abstract}
Apparel industry plays an important role in the economic and social development of Bangladesh. This is now a multi-billion dollar manufacturing and export industry in Bangladesh. Its contribution to the foreign exchange earnings, poverty alleviation through creating employment opportunities and empowerment of women is remarkable. However, global competition and unstable market conditions prompted manufacturers to review their traditional manufacturing strategy. In today's competitive business world, manufacturers are using Lean Manufacturing (LM) technique in order to improve performance and competitiveness. Lean Manufacturing (LM) is a holistic and sustainable approach of manufacturing system used for creating value for customers through eliminating waste in the manufacturing processes. This conceptual paper addresses the concept of lean manufacturing, its benefits and the challenges of implementing lean manufacturing
\end{abstract}

Keywords: Apparel industry, Lean manufacturing, Manufacturing Competitiveness, Benefits, Performance.

\section{Introduction}

The RMG industry of Bangladesh plays a vital role in the economic and social development of Bangladesh. Bangladesh is now the second largest apparel exporting country in the world after Chain. The apparel industry is now acting as the backbone of the economy of Bangladesh. The apparel industry of Bangladesh experienced phenomenal growth after started its journey in the year 1970s. Reaz garment was the first direct apparel exporter and exported 10,000 units of men's shirt to a Paris-based firm in 1978 [1]. Total export value of the garments was 13 million French francs. Late Mr. Nurul Qader Khan is also called the pioneer of the Ready-Made Garment industry set up his first apparel factory "Desh Garments" in alliance with South Korean firm Daewoo in 1979 [1]. The apparel industry is now a multi-billion dollar export-oriented industry. The apparel industry has achieved a high profile of growth in terms of industrialization, foreign exchange earnings and contribution to GDP.

In the age of global business competition, manufacturing firms are under continuous pressure to improve their performance for survival. The apparel manufacturing firms in Bangladesh are also facing the heat of global competition due to the industrial liberalization and introduction of open market policies. Despite the remarkable contributions, the apparel manufacturers are facing various challenges to meet the customer's demand and expectations. However, global competition and unstable market conditions prompted manufacturers to review their traditional manufacturing strategy [2]. Therefore, this conceptual paper addresses the growth, benefits, and challenges of lean implementation.

\section{Growth of Garment Factories}

The progress of apparel industries in Bangladesh is significant. Figure 1 shows a tremendous growth rate of the garment industries from 1990 to 2012. Over the last 30 years (from 1984-85 to 1915-16), the number of garments has grown from 384 to 4328 in numbers. Few garments were forced to shut down after the painful incidents of Rana Plaza and Tazreen Garment. The highest numbers of garments (5876) were in operations in the year 2012-2013. Most of the apparel industries are located in the three main cities of Bangladesh. These are the capital city Dhaka, the port city Chittagong and the industrial city Narayangonj. 


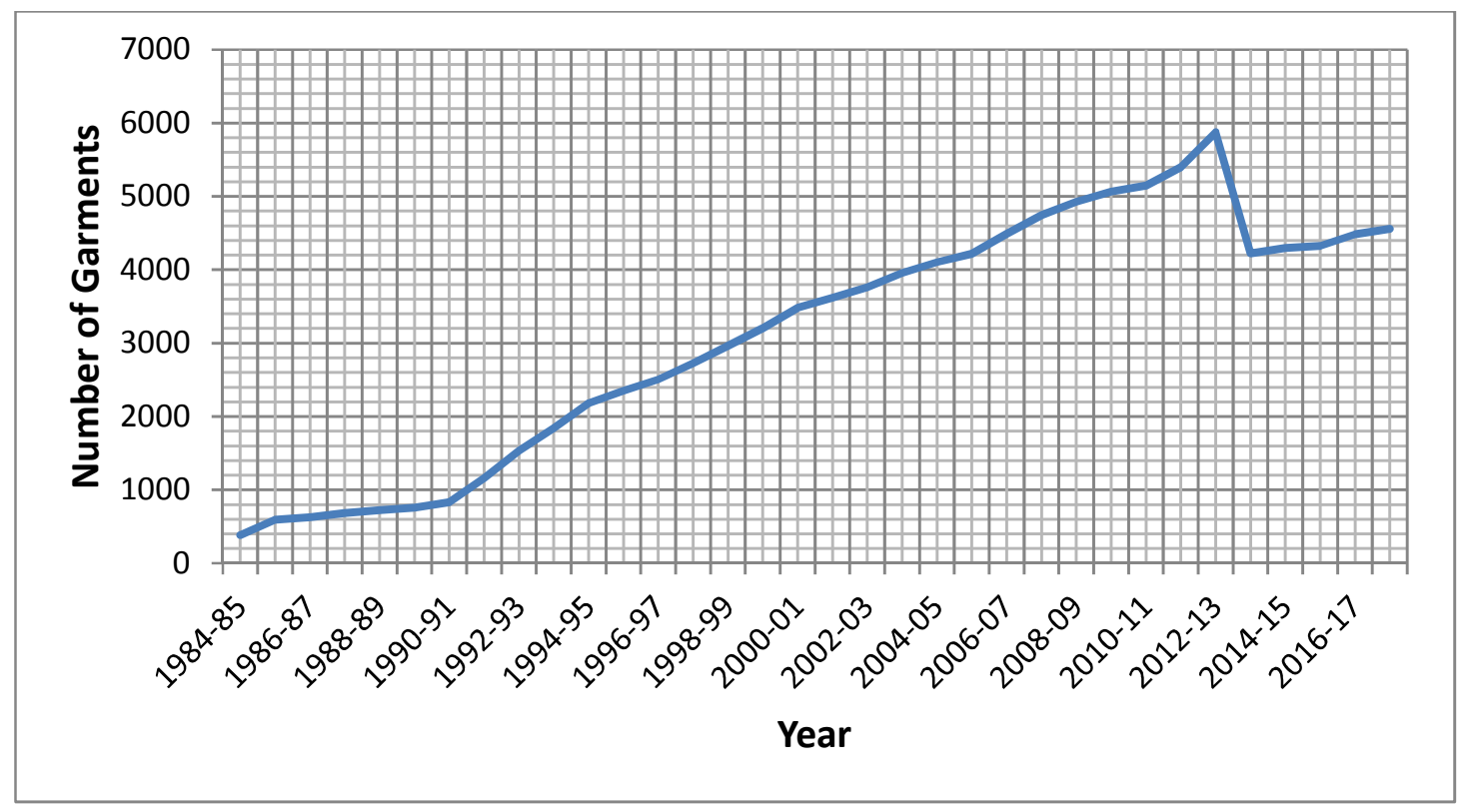

Figure 1: Growth of Garments Factories. Data Source: BGMEA.

\section{EMPLOTMENT GROWTH}

The growth of RMG industry has generated huge employment opportunities in Bangladesh. The employment growth of RMG sector is significant and the total employment increased from 0.12 million
(1984-85) to 4 million (2016-2017) within the last 30 years. Now four million workers are directly employed in this industry and more than 12 million inhabitants are indirectly associated with the apparel industry.

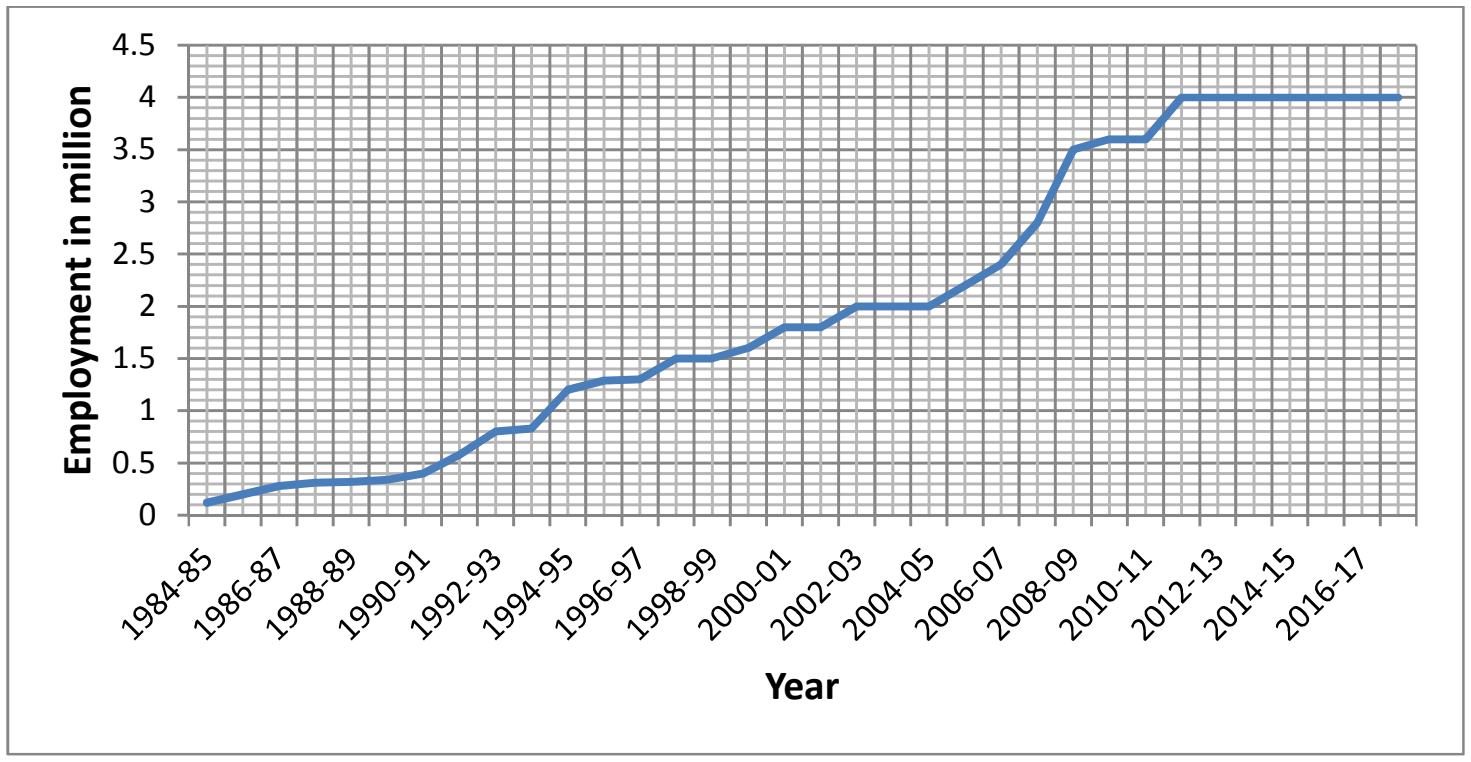

Figure 2: Employment Growth (in millions). Data Source: BGMEA. 


\section{RMG CONTRIBUTION TO EXPORT EARNINGS}

The apparel industry is now the single biggest export earner for Bangladesh. Now the apparel industry is a multi-billion dollar export-oriented manufacturing industry. In the year 1984-15, the total export earning was 31.57 million US\$. The export earnings increased from 31.57 million US\$ to 25491.40 million US\$ within 30 years of time span (1984-85 to 2014-15). This is a growth of $80745.64 \%$ over a period of 30 years (Figure 3 ). Figure 3 shows that the export earnings reached to 5000 million US\$ from 31.57 million US\$ over the 20 years of time (1983-84 to 2002-03). But this export accelerated for the next 12 years of time
(2003-04 to 2014-15) and reached to 25491.4 million US\$.

\section{CONTRIBUTION OF APPAREL INDUSTRY TO THE TOTAL EXPORT EARNINGS}

The contribution of the apparel industry to the total export of the country is shown in figure 4. In the year 1983-84, the RMG's contribution to the total country's export was only $3.89 \%$. But this contribution reached to $81.71 \%$ in the year $2014-$ 15. The apparel industry now is the single biggest export earner for the country. It plays a great role and making a crucial contribution to rebuilding the country and its economy.

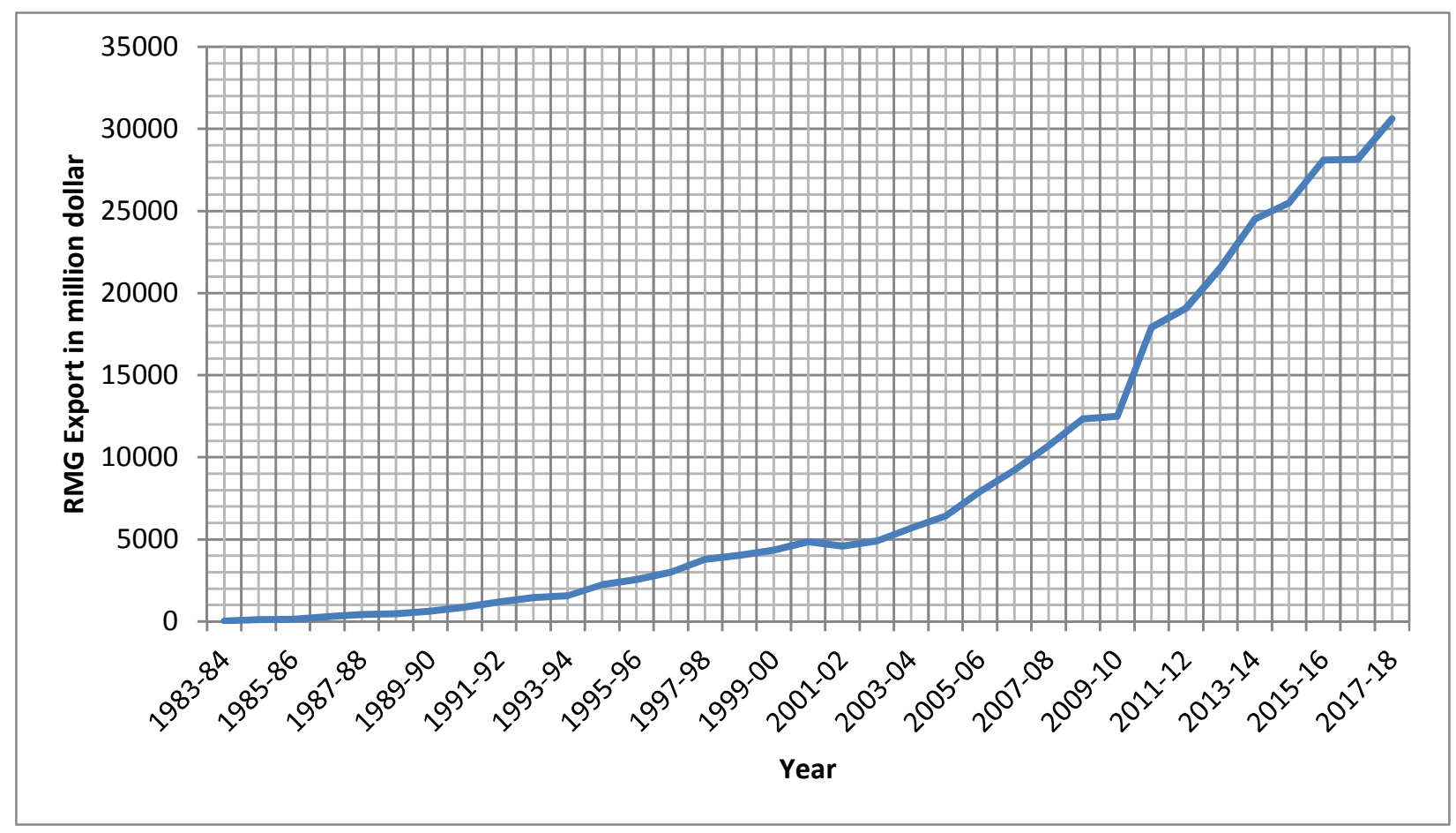

Figure 3: Export Growth of RMG (1983-84 to 2017-2018).

Data Source: Export Promotion Bureau Compiled by BGMEA.

\section{CHALLENGES OF APPAREL INDUSTRY}

The tremendous growth of the apparel industry in terms of contribution to GDP, foreign exchange earnings, export growth, and employment is well recognized. Despite the remarkable success, the apparel manufacturers are facing several challenges from the buyers. The buyers are more concern about social compliance. The global competition is fierce and the manufacturers need to achieve the competitive advantages in terms of cost of production, quality improvement, reducing manufacturing and delivery lead time. With rising unemployment in the U.S and E.U, the consumers 
have reduced their spending which adversely affected the apparel industry.

In this highly competitive environment, apparel manufacturers need to face the challenges and make a difference that will attract international buyers. The challenges of reducing the production costs, reducing manufacturing and delivery lead time, and achieving better quality and response time performance demand adoption of advanced manufacturing philosophy such as lean manufacturing.

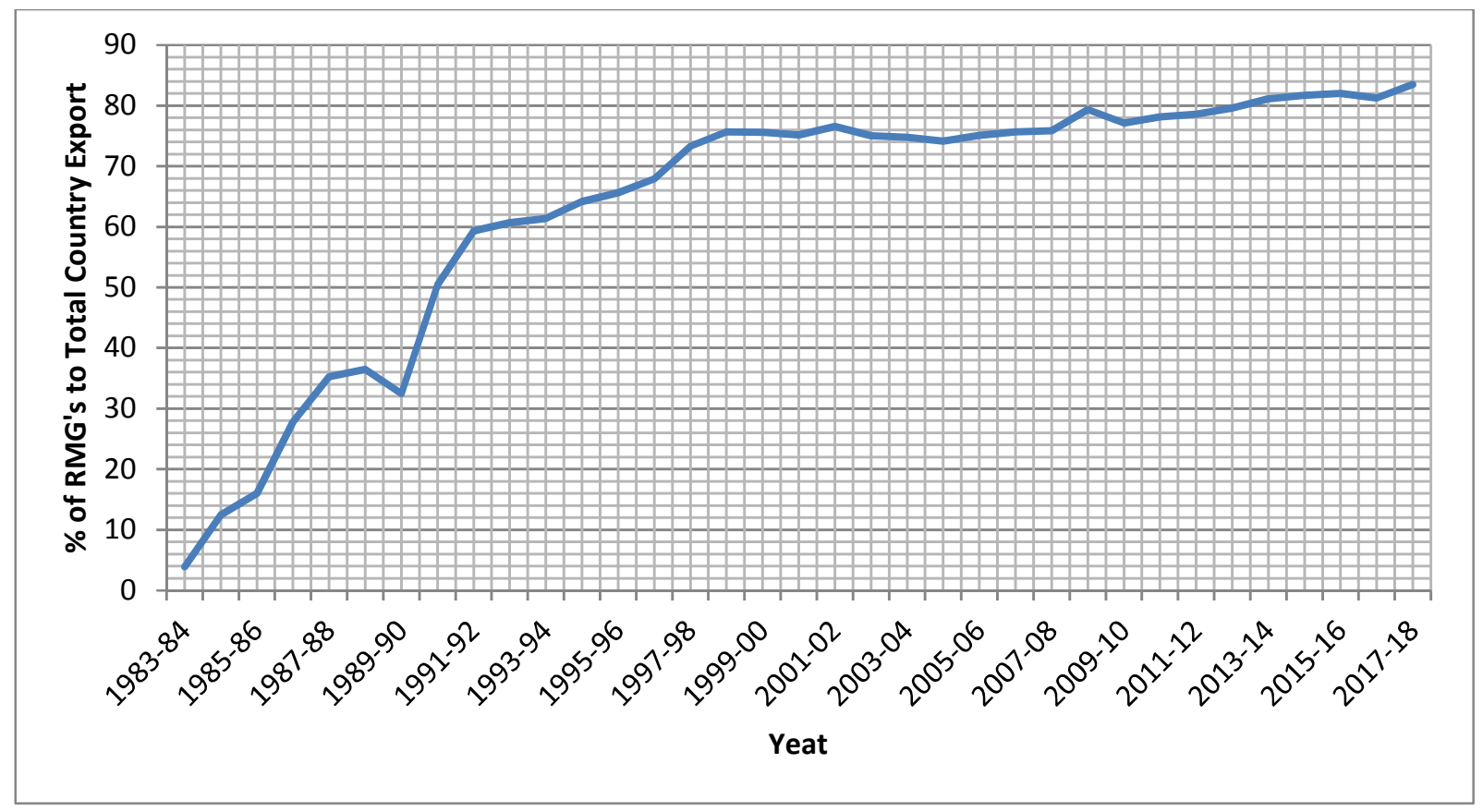

Figure 4: Export Growth of RMG Compare to Total Export (1983-84 to 2017-2018) Data Source: Export Promotion Bureau Compiled by BGMEA

\section{LEAN MANUFACTURING}

Lean manufacturing is a comprehensive set of techniques that, when combined and implemented will reduce and then eliminate the seven wastes. This system not only makes the company leaner but subsequently makes flexible and more responsive by reducing waste [3]:

\section{Lean manufacturing}

“..... is "lean" because it uses less of everything --half the human effort in the factory, half the manufacturing space, half the investment in tools, half the engineering hours to develop a new product in half the time. Also, it requires keeping far less than half the needed inventory on site, results in many fewer defects, and produces a greater and ever-growing variety of product" [4].
The idea of lean production originated from the Toyota Production System (TPS). Ohno [5] made three important statements in his book, 'The Toyota Production System Beyond Large Scale Production" as follows.

- "The basis of the Toyota production system is the absolute elimination of waste."

- "Cost reduction is the goal."

- "After World War II, our main concern was how to produce high-quality goods. After 1955, however, the question became how to make the exact quantity needed."

In the 1980s, a research group at Massachusetts Institute of Technology (MIT) investigated the success of TPS and the output of the research findings summarized in the book "The Machine That Changed 
The World" [4]. That was the story of Lean Production (LP) which compares LP with Henry Ford mass production system and points out the advantages of the LP system [6]. MIT study provided strong evidence that the manufacturers implementing lean had better quality, cost and response time performance. Womack \& Jones [7] and Wilson [3] suggested that the main thrust of the lean concept is the total elimination of waste from all production processes [8].

\section{LEAN MANUFACTURING AND WASTE ELIMINATION}

The goal of lean implementation is to identify and eliminating non-value added activities from the production system. Lean is an integrated approach to waste elimination [9]. The concept of waste originated from the Toyota Production System (TPS) and waste is anything that interfere the smooth flow of production [10]. The benefits of lean manufacturing are well recognized and the manufacturers are implementing LM because it helps an organization to do more with less. The basis of LM is the absolute elimination of 7 wastes as follows:

- Over Production: Producing more product than the customer currently demands

- Unnecessary Transportation: Moving raw materials, work-in-progress and finished goods needlessly

- Excess Inventory: Keeping more raw materials work-in-process and finished goods than needed on site.

- Waiting: The workers or the machine is waiting for materials or information

- Over Processing: Doing more work than the customer requires

- Excess Motion: Workers make unneeded movements in the production process

- Defects: Producing more defective items that impact the customers

\section{Benefits of Lean Manufacturing}

The objective of LM is to achieve competitive advantages. A manufacturing firm using traditional mass production can expect a reduction of lead time of $90 \%, 90 \%$ reduction of inventories, cost reduction of $90 \%$ and a labor productivity improvement of $50 \%$ through the implementation of lean manufacturing system $[11,12]$. Many organizations have implemented lean manufacturing system successfully enjoy the benefits of lean. But the misapplication of lean tools and techniques makes the organization unsuccessful. The reasons for misapplication are the use of the wrong tools or use the same tools for solving all problems [13].

The benefits of LM in non-process industries are well documented [14]. The benefits are as follows:

- Reduced inventory position

- Increased process understanding of the whole supply chain. Reduced lead time for customers

- Less process waste

- Fewer errors and therefore Less rework

- Significant financial benefits through faster business process and lower operating cost

\section{The Challenges of Lean Implementation}

The benefits of lean implementation are well recognized and supported by the literature. But the implementation process always faces several challenges. There are supporting and resisting forces for lean implementation. The supporting forces are the benefits of lean implementation whereas the resisting forces are resisting to the change as shown (Figure 5) in the Melton model [14]. The equilibrium will change when the driving forces are stronger than restraining forces. Successful change will be achieved by either strengthening the driving forces or by weakening the restraining forces. This model is similar to the Lewin force field model.

The main barriers of lean implementation are the lack of lean awareness, lack of sufficient resources, misunderstanding of lean concept, resistance from the employees and implementing lean without setting specific goal. The apparel manufacturing firms need strategic planning to overcome all the barriers to lean implementation. 


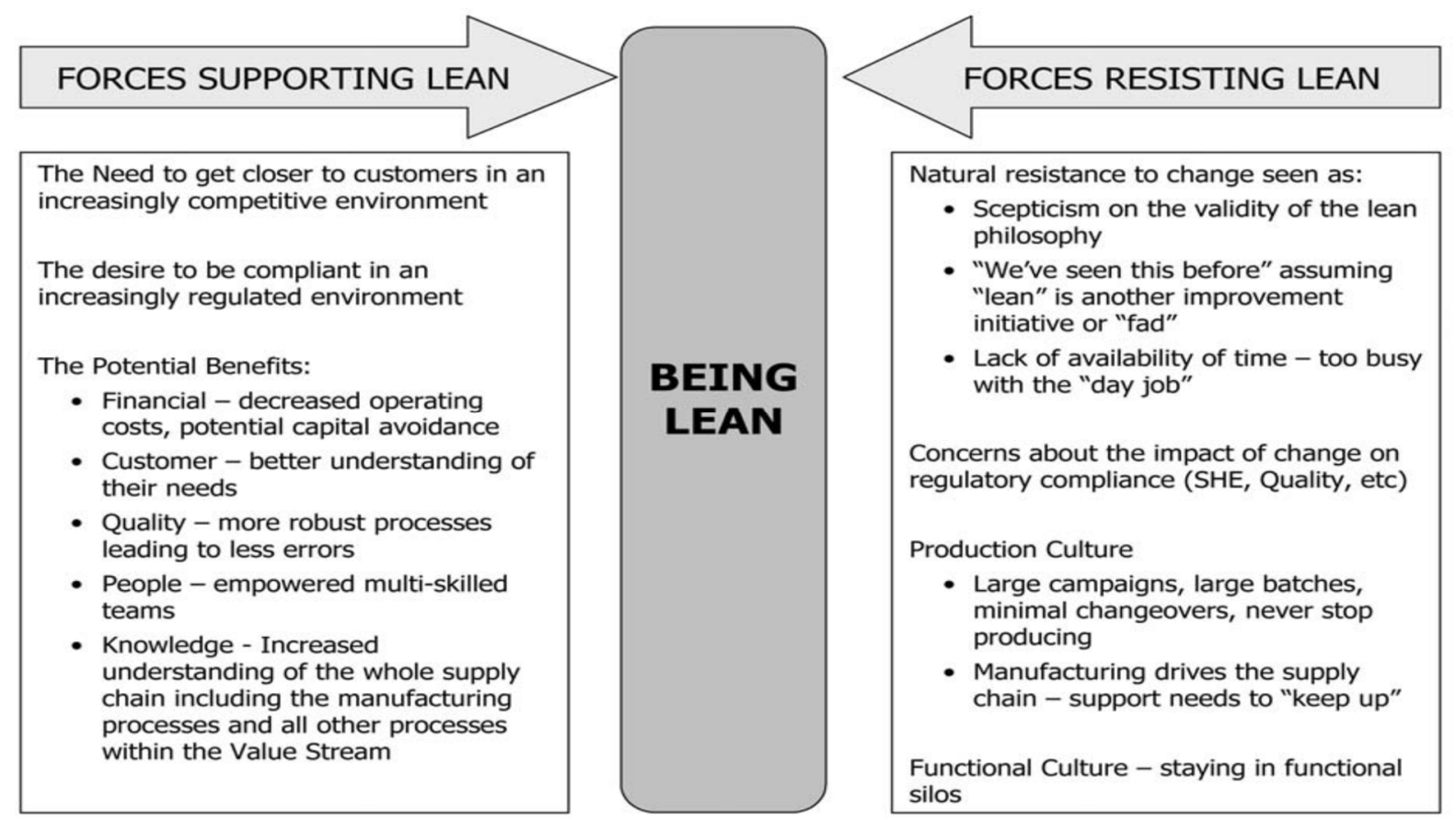

Figure 5: The Forces Opposing and Driving a Change to Lean. Source: (Melton, 20050).

\section{CONCLUSION}

The manufacturing competitiveness is the key to success for the apparel industry in Bangladesh. The apparel manufacturers need to implement lean manufacturing philosophy as an integrated approach to get the full benefits of the LM system. The apparel manufacturers need to take the implementation initiative of LM manufacturing system to achieve the competitive advantages in terms of productivity, quality, inventory reduction, lead time reduction, customer satisfaction, sales, and profitability. BGMEA and BKMEA must take the initiative to implement lean manufacturing system and enjoy the benefits of successful lean implementation.

\section{References}

[1] F. Ahmed, "Background of History of Bangladesh and Ready-made Garment Industry: Key challenges in the RMG Industry," Middle East Journal of Business, vol. 8, no. 1, pp. 33-52, 2013.

[2] S. Ismail Salaheldin and R. Eid, "The implementation of world class manufacturing techniques in Egyptian manufacturing firms: An empirical study," Industrial Management \& Data Systems, vol. 107, no. 4, pp. 551-566, 2007.

[3] L. Wilson, How to implement lean manufacturing (I. Mcgraw-Hill companies). 2010.

[4] J. P. Womack, D. T. Jones, and D. Roos, Machine that changed the world. Simon and Schuster, 1990.

[5] T. Ohno, Toyota production system: beyond largescale production. crc Press, 1988.

[6] M. Alemi and R. Akram, "Measuring the leanness of manufacturing systems by using fuzzy TOPSIS: A case study of the'Parizan Sanat'company," South African Journal of Industrial Engineering, vol. 24, no. 3, pp. 166-174, 2013.

[7] J. P. Womack and D. T. Jones, "From lean production to lean enterprise," Harvard business review, vol. 72, no. 2, pp. 93-103, 1994.

[8] F. Pakdil and K. M. Leonard, "The effect of organizational culture on implementing and sustaining lean processes," Journal of Manufacturing Technology Management, vol. 26, no. 5, pp. 725-743, 2015.

[9] R. Shah and P. T. Ward, "Defining and developing measures of lean production," Journal of operations management, vol. 25, no. 4, pp. 785-805, 2007.

[10] J. P. MacDuffie and S. Helper, "Creating lean suppliers: diffusing lean production through the 
supply chain," California Management Review, vol. 39, no. 4, pp. 118-151, 1997.

[11]D. Lathin and R. Mitchell, "Lean manufacturing," American Society for Quality Journal, no. December, pp. 2-9, 2001.

[12] S. Bhasin and P. Burcher, "Lean viewed as a philosophy," Journal of manufacturing technology management, vol. 17, no. 1, pp. 56-72, 2006.
[13] S. Pavnaskar, J. Gershenson, and A. Jambekar, "Classification scheme for lean manufacturing tools," International Journal of Production Research, vol. 41, no. 13, pp. 3075-3090, 2003.

[14] T. Melton, "The benefits of lean manufacturing: what lean thinking has to offer the process industries," Chemical engineering research and design, vol. 83, no. 6, pp. 662-673, 2005. 